811.163.41'373.43

https://doi.org/10.18485/msc.2018.47.3.ch6

\author{
Александар М. МИЛАНОВИЋ \\ Филолошки факултет \\ Универзитета у Београду
}

\title{
ЛЕКСИЧКИ АРХАИЗМОИДИ ТЈ. ПСЕУДОАРХАИЗМИ У САВРЕМЕНОМ СРПСКОМ ЈЕЗИКУ
}

\begin{abstract}
У раду се анализирају архаизмоиди, тј. неологизми, најчешће индивидуализми, свесно настали по архаичном творбеном типу или помоћу архаичних творбених морфема. У србистичкој литератури називају се још и псеудоархаизмима. Утврђује се њихово порекло и стилска функција (стилогеност) у публицистичком и књижевноуметничком стилу савременога српског стандардног језика.
\end{abstract}

Кључне речи: архаизмоид, псеудоархаизам, неологизам, индивидуализам, архаизам, славенизам, творбени тип, творбена морфема, композиција, стилогеност

1. О терминима. Неологизми, најчешће индивидуализми, свесно настали по архаичном творбеном моделу, тј. творбеном типу како их назива савремена дериватологија (Ћорић 2008: 32), или помоћу архаичних творбених морфема, који су у овоме раду називани архаизмоидима и који се у србистичкој литератури одређују и као псеудоархаизми, нису до сада привлачили превише пажње дериватолога, лексиколога и стилистичара. ${ }^{1}$ Тако се у монографији посвећеној неологизмима у хрватском језику (Мухвић Димановски $2005)$, и поред свестраног увида у разнолике видове неологизације, не констатује овај тип нових речи. ${ }^{2}$ Наша прва напомена о овоме специфичном лексичком слоју односи се на селектовани термин. Термин архаизмоид сматрамо адекватнијим јер у србистичкој терминологији већ постоје термини изведени суфиксоидом -оид, са семантичком компонентом 'налик на' (нпр. суфиксоид

\footnotetext{
*aleksandar.jus@gmail.com

${ }^{1}$ Овај тип нових лексема није регистрован ни у веома детаљном увиду у неологизме и индивидуализме у савременом српском језику, дат у Драгићевић 2018.

${ }^{2}$ Сасвим су друго неологизми које ауторка терминолошки одређује као оживљенице: „U neologizme se jednako tako mogu ubrojiti i ponovo oživjele domaće riječi - oživljenice - koje su zbog različitih razloga bile dulje vrijeme potiskivane ili čak zabranjivane za uporabu: premda stare po svojemu postanku, one su ipak nove za mnoge generacije suvremenih korisnika, a u ranijim se rječnicima javljaju kao arhaizmi, u istom, ali često i u potpuno drugačijem značenju" (Мухвић Димановски 2005: 63).
} 
и префиксоид), ${ }^{3}$ што је због системности увек пожељно чак и када јединице не припадају истом (под)систему: суфиксоид и префиксоид су творбене морфеме, док би архаизмоид био лексема, или пак синтаксичка јединица. ${ }^{4}$ Први пут смо овај термин употребили анализирајући архаизовани језик савремене српске прозе (Милановић 2003: 127).

Са друге стране, у србистици нема распрострањенијих лингвистичких термина са префиксоидом псеудо- (*nсеудосуфикс, *nсеудопрефикс и сл.), ${ }^{5}$ а овај термин може изазвати и нежељене конотације везане за семантичку компоненту 'лажни' јер „први део сложеница [...] означава нешто лажно, привидно, тобожње” (Клајн/Шипка 2008: 1016). ${ }^{6}$ Аргумент у прилог термина nсеудоархаизам је традиција, односно његова потврђеност, додуше ретка, у литератури (нпр. Клајн Клајн 2003: 185). ${ }^{7}$

2. Друштвеноисторијски контекст. Да би се схватила мотивација за стварање савремених архаизмоида у српском језику и нарочито њихова стилска функција тј. стилогеност, ваља указати на друштвеноисторијски контекст новијег развоја српског језика. ${ }^{8}$ Као и сваки револуционар, Вук Караџић је у своју књижевнојезичку реформу кренуо негирајући постојећу традицију, па је у полемици са Милованом Видаковићем руглу извргао сладуњаву сентименталистичку књижевност, стварану на славеносрпском језику, са пуно ироније у распону од простонародне шаљивости до сарказма, пишући и о њеној ненародној лексици, презасићеној славенизмима. Овакав однос према лексичким славенизмима, без обзира на њихово порекло, ${ }^{9}$ одомаћио се код многих романтичарских писаца већ средином 19. века јер су ненародне речи третиране као стилска слабост српског сентиментализма и класицизма, речи које су подједнако удаљене од израза и народне и романтичарске поезије. Наравно, било је и значајних изузетака, па је тако Лаза Костић у своју поезију уградио и лексичко наслеђе везано за црквенословенску традицију. ${ }^{10} \mathrm{y}$ живом говору су, пак, славенизми уз несловенске позајмљенице временом све више доживљавани као израз градске снобовштине или пак малограђанштине, за шта пуно ироничних потврда налазимо у српској драми, пре свега код Јована Стерије Поповића.

2.1. Промене у српској књижевности и српском друштву у епохи романтичарског националног заноса изазвале су и промену односа према лексичким славенизмима, па су они престали бити престижна одлика високог

${ }^{3}$ Упор. Клајн/Шипка 2008: 850: „који је сличан нечему, који припада одређеној врсти; који је замена за нешто".

${ }^{4}$ В. напомену о синтаксичким архаизмоидима у закључку.

${ }^{5}$ У синтакси се, на пример, спорадично употребљава термин псеудоагенс. У кроатистици се користи и термин псеудопосуђенице (Мухвић Димановски 2005: 47).

6 Занимљиво, у Клајн/Шипка 2008 међу примерима са префиксоидом псеудо- нема лексеме псеудоархаизам, коју Клајн 2003 очито употребљава као радни термин.

${ }^{7}$ На пример, овог термина нема у СХJ 1971.

${ }^{8}$ У овом краћем опису истичемо само кључне детаље који су релевантни за тему рада, а важни су за сагледавање статуса лексике различитог порекла у периоду од 19. до 21. века.

${ }^{9}$ Под славенизмима, у складу са погледима Светозара Стијовића (1992), подразумевамо лексеме из српскословенског и рускословенског језика, као и славеносрбизме, тј. лексичке хибриде.

${ }^{10}$ В. Грковић-Мејџор 2011. 
стила, као у сентименталистичкој прози Милована Видаковића или класицистичкој поезији Лукијана Мушицког, а у другој половини 19. века жигосани су као све мање пожељни у стандардном језику, иако је неке од њих, додуше само оне који су се одомаћили у народном језику, унео у оба издања Српског рјечника. Иако су се постепено, али све убрзаније, повлачили из израза српске књижевности, науке, публицистике и администрације, лексичке славенизме је још увек могуће релативно лако наћи у српском стандардном језику и крајем 19. века, нарочито у језику српских канцеларија.

2.2. После коначне Вукове победе над славеносрпским језиком у другој половини 19. века, послевуковци су тежили стабилизацији српскога стандардног језика кроз идеју о канонизацији Вукових и Даничићевих језичких решења. Нудећи Вуков и Даничићев језик као идеалан и не увиђајући да се српски језик са развојем културе неминовно мења, представници „филолошке критике” критиковали су са позиција „чистоте” језика књижевног дела сваку изражајну иновацију. Како је језик къижевности представљан у 19. веку као једини престижан облик стандардног језика, и остали српски ствараоци - пре свих научници, публицисти и новинари, морали су поштовати застареле језичке савете и поуке „филолошке критике”, плашећи се јавне осуде за недовољно култивисан језички израз. Однос према славенизмима постао је још ригиднији но у Вуково време, а „филолошка критика” могла је пратити напоредо повлачење овог лексичког слоја у различитим функционалним стиловима.

2.3. Први прави талас модернизације српског стандардног језика пристигао је на самом крају 19. и почетком 20. века, у епохи „београдског стила". Иако су сви његови представници остали сасвим у оквирима вуковске матрице, што је први констатовао Александар Белић већ тридесетих година 20. века, језичке иновације у језику престижних књижевника, научника и новинара биле су евидентне како на лексичком тако и на синтаксичком плану. Са једне стране, снажан продор нове лексике страног порекла, нарочито интернационализама (европеизама) и галицизама, али и постепени уплив англищизама, а са друге стране потпуно потискивање лексичких славенизама - и то истовремено и изведеница и сложеница црквенословенског или славеносрпског порекла - потпуно су изменили и обновили лексичку слику српске књижевности, науке и публицистике.

Већ у поезији српске модерне (Јован Дучић, Милан Ракић, Сима Пандуровић и др.) славенизама више нема, али у тој стилској формацији нема ни ироничног односа према лексичком наслеђу црквенословенске културе нити у поетичким исказима самих песника нити у престижној књижевној критици Богдана Поповића, Јован Скерлића или Павла Поповића. Ова лексика повлачи се и из израза српске прозе (Бора Станковић, Стеван Сремац, Симо Матавуљ, Милутин Ускоковић и др.), али и из језика српске науке (Слободан Јовановић, Јован Цвијић, Александар Белић, Михаило Петровић Алас и др.) и журналистике (новинари Политике и других дневних новина и часописа).

2.4. Нова епоха авангардне поезије доноси очекивани изражајни отклон према високостилизованој поезији модерне и стилистичким погледима Јова- 
на Скерлића и браће Поповић, али она у том циљу језички одлази корак даље, а не два корака уназад. Зато архаичне лексике која асоцира на књишку културу прошлости нема ни у авангардном песничком изразу Милоша Црњанског или Станислава Винавера. Међутим, сасвим новим поетичким путем кренуо је Момчило Настасијевић, враћајући се и у поезији и у прози језичкој патини нашег културног наслеђа и захватајући истовремено из цркевнословенског и фолклорног резервоара.

3. Утицај идеологије. Сасвим нова епоха у односу према застарелом језичком наслеђу стиже са променом политичког и идеолошког система после Другог светског рата. После победе марксиситичких, комунистичких идеја у новој држави, на целокупну црквенословенску лексику почиње се гледати као на продукт вишевековног културног па и државног утицаја српске цркве, са којом се нова југословенска идеологија брутално разрачунавала и кроз повишену ангажованост књижевне критике. Одраз тог обрачуна заснованог на идеолошким догмама био је више него видљив у култури пре свега током 50-их година 20. века. Надреалистички књижевник Оскар Давичо у књигама есеја Поезија, отпори и неотпори (Давичо 1969) и Rituali umiranja jezika (Давичо 1974) сведочи да притисак на српско духовно наслеђе не престаје ни током 60-их и 70-их година прошлог века.

Иста идеолошка матрица лако се уочава и у филолошкој науци и есејистици, понекад чак и у радовима високо вреднованих и позиционираних научника, на пример Миодрага Поповића или Михаила Стевановића (Милановић 2002). Лексички славенизми постали су у епохи југословенског комунизма упечатљиви експоненти свега назадног, буржоаског, реакционарног, нејугословенског, нетитоистичког и великосрпског, а самим тим непожљени у било којем типу дискурса или текста, осим ако нису били у функцији ироније или сарказма. Са друге стране, није на исти начин била прогнана архаична фолклорна и народна лексика: овековечена је била, уосталом, и у Вуковом стваралаштву, а реформатор српског језика, писма и културе представљан је у Титовој Југославији, нарочито у СР Србији, као родоначелник идеје братства и јединства и праотац југословенских пролетера, без обзира на потпуну ненаучност таквих поставки.

Тако је и у Давичовом фокусу напада на архаичну лексику у језику књижевног дела управо црквенословенска лексика, али не и она дијалекатска, активирана на пример у Крлежином опусу: „Ali ima i pesnika koji, osećajući slabost običnih reči književnog jezika, jezički ne beže uvek u manastirska srednjovekovlja, nego u pučke i laičke dijalekte. Ne manje srednjovekovne. Petrica nije promašaj, nego domet. Uprkos svojoj dijalektalnosti. Ali i zato što, ne budući dijalektalno autentičan, donosi na dijalektalnoj osnovici jedan neponovljiv, silovito individualiziran jezik, semantički i sintaktički moderan, složen, smeo i kulturno razuđen” (Давичо 1974: 85). Посезање за лексиком „манастирског средњовековља" априорно се код једног од кључних естетичких и поетичких судија оцењује као промашај и тако се шаље сасвим јасна порука српским песницима каква их рецепција чека, док се песничко оживљавање кајкавског наречја глорификује као „домет” 
Писац који би се после 1945. у своме стваралаштву ослонио на црквенословенско лексичко наслеђе био је, дакле, осуђен на негативну рецепцију оног дела књижевне критике блиског власти, а самим тим и најутицајнијег дела у јавности: у блажем случају на игнорисање, у тежем - на њихове нападе.

У раду о Давичовом односу према црквенословенском лексичком наслеђу (Милановић 2005) већ смо констатовали да овакво закључивање о језичкој ситуацији после 1945. године није произвољно, односно без јаке научне основе, и да о њој најилустративније сведоче и стилистичке монографије и уџбеници Милорада Ћорца, универзитетског професора из Приштине и истакнутог партијског радника, у којима црквенословенској лексици приписује искључиво „хумористичку и сатиричну изражајну вредност” јер она искључиво служи „за грађење ликова конзервативне свијести, за сликање личности и средина које имају било какву везу са религијом или с неком вјероисповеденом установом" (Һорац 1968: 102-104, Ћорац 1974: 30).

4. Иронијска компонента. Дужи осврт на друштвеноисторијске прилике у српској стандарднојезичкој прошлости био је неопходан у потрази за одговором на питање зашто су лексички славенизми тако често у нашој публицистици и есејистици активирани у циљу постизања ироније. Традиција која креће од Вуковог односа према славеносрпском језику, а коју - сваки из другачијих поетичких разлога - настављају српски романтичари, модернисти и авангардни књижевници, условила је и данашњи подругљив и подсмешљив поглед на архаизме из српске књишке, црквене прошлости. Потпуно исту стилску функцију често добијају и архаизмоиди грађени помоћу уочљивих творбених морфема из српске или руске редакције старочрквенословенског језика, било да су у питању изведенице са типичним суфиксима (нпр. -ије, -тељ, -аски/-ески и сл.) или сложенице налик на црквенословенске (нпр. као најтипичније оне са првим елементом бого-, много-, благо- и сл.). ${ }^{11}$

4.1. Увидом у корпус може се констатовати појава да се чак исти архаизмоид појави у језику различитих аутора, где можемо говорити и о поступку интертекстуалности. Тако је доста пре више деценија угледни књижевни критичар Зоран Мишић (1996), у карактеристичном контексту исказа који дефинише стилску позицију и ауторов став, сковао архаизмоид марксиствујушчи, који је по своме фонетском склопу несумњиво налик на партиципе из рускословенског језика, али са творбеном основом која ствара додатни стилски ефекат парадоксалне целине: „Јер књижевна критика одавно више није оно што свакојаки филистри и педанти, макар и марксиствујушчи, и остали рачуноиспитивачи немерљивих количина желе да буде.” Исти архаизмоид користи више деценија касније и Славко Кордић (2011), и то у сличном контексту: „Иво Андрић, знамо, није превасходно марксиствујушчи дух - мада средином столећа, као и толики други, каткад у својим чланцима и говорима помиње капитализам и експлоатацฺију.”

${ }^{11}$ Типичан у том смислу био би пример архаизмоида благомргодни из прозе Мирослава Јосића Вишњића, или примери многолеп и многострашан из прозе Горана Петровића (Милановић 2003: 133-134). 
4.2. Одавно је и Оскар Давичо (1974: 47), у књизи Rituali umiranja jezika, активирао архаизмоид филозофствуjући, вуковски посрбљавајући групу /šč/ у /ć/ у исказу у којем констатује „,da je otud sinhronija, u najboljem slučaju, samo jedna radna pretpostavka, valjana možda za prvu etapu ispitivanja jezika kao sistema, ispitivanja što treba čim pre da se oslobodi izlišnih filosofstvujućih implikacija nakupljenih usput”. Враћајући му руско тј. рускословенско рухо, за готово истим архаизмоидом, сада у форми философствујушчи и у склопу полусложенице, посеже и Јован Делић (1997: 99): „Таква тематика данас је ризична; лако може одвести у празну патетику, у кич, у догму, у сусједство баналности, у религијско-философствујушче мудровање.” Мотивација за активирање готово истог архаизмоида, међутим, код Давича и Делића посве је различита. Давичо наступа са позиција отвореног борца против црквене традиције у југословенској култури, Делић готово четврт века касније стоји на сасвим супротној позицији, сада у контексту само српске културе. Обојица, ипак, посежу за истом стилемом, обојица њену стилогеност виде у просторима ироније и хумора, које Делић додатно појачава лексемом мудровање. Коначно, код Делића је додатно појачана подругљивост као емотиви нанос у овој критици појединих приступа књижевном делу.

Будући да су архаизмоиди јасно и наглашено обележени фонетски и деривационо, њихову стилематичност можемо утврдити и ван реченичног контекста. Стилогеност њихову, међутим, морамо утврђивати пажљивом анализом контекста и корелација између архаизмоида и друге стилски обележене лексике у блиском текстуалном окружењу. Нова Давичова реченица доноси архаизмоид атеиствујушчи, која у контексту директно корелира са иронично употребљеном рускословенском предлошко-падежном конструкцијом во времја, а смисао читаве реченице недвосмислено одређује позицију аутора и његове разлоге за подругљив тон:

„Казао сам 'магија', али упркос мојим атеиствујушчим наводницима, ја знам да су некад постојале хипнотишуће речи тајанствене и тајне, а и ви знате да ми је пао на памет читав театарски ритуал око изговора правог имена господа, коме су се, во времја, подавали непосвећени и левити, будући да га је знао само првосвештеник" (Давичо 1969: 212).

Кумулација архаизмоида није чест стилски поступак у српској књижевности, а разлоге овој појави треба тражити пре свега у нежељеном стилском ефекту презасићености који се може појавити код читалаца, а који добро језичко осећање писаца несумњиво препознаје као опасно. Ретки примери ипак доказују да кумулација може бити и стилски ефектна, као у случају линеарног низања готово парадоксалних архаизмоида у Давичовој књизи Rituali umiranja jezika:

„Jer primitivizam za primitivizam, ali ja nisam nikad bio za onaj ždanovski; još manje može onaj nacionalističko-pravoslavstvujušči-jevrejstvujušči-islamujušči ili katolikujušči predstavljati iskušenja za mene" (Давичо 1974: 38).

5. Стилогеност архаизмоида у књижевноуметничком стилу. Архаизмоиди у језику књижевности добијају, наравно, и друге, разноврсније функције које је тешко класификовати. Постоје, ипак, и одређене константе 
при стварању архаизмоида у језику есеја, публицистичког текста и књижевног дела. Прва се односи на жељу аутора да у свим овим стиловима створе лексему налик на застарелу, али коју ће читаоци ипак лако детектовати као нову. Ту стилску игру детерминише типични читалац: у новинском тексту архаизмоид мора бити лако препознатљив да би постигао стилски ефекат код најшире публике; књижевник или књижевни тумач, с друге стране, рачуна на пажљивог и посвећеног читаоца, спремног да дубоко анализира његове стилске поступке и решења.

5.1. Тако Милосав Тешић (1996: 140), у збирци Прелест севера, круг рачански, Дунавом која песнички дочарава историјску трагику и узвишеност српског 18. века, ствара архаизмоид удареније, нову изведеницу са архаичним, црквенословенским суфиксом -ије, и смешта га у одговарајући контекст песме „Двојица Рачана, простих монаха, Порфирије и Георгије: Разговор при плевљењу и окопавању повртьака у Беочину”. Ова песма је стилски сасвим несвојствена за Тешићеву поезију, готово је изузетна у односу на све друге због ласцивног тона, изнетог кроз двосмислености, као доминантног у „опису” разговора двојице простих монаха, од којих један „изговара”:

А ту ли лежи оно мњеније

что крепи твоје удареније!

Архаизмоид удареније вешто је уклопљен међу архаизме (мюеније, что), чиме се актуелизује „говор” простог монаха из далеке прошлости, а све три лексеме додатно су као графостилеме истакнуте и курзивом. Иако лексема удареније постоји још у српскословенском периоду у значењу ,'ударање, удар, ударац' [...]” нарочито као „’звучни удар, звонко ударање у [...] било', чиме се братија позивају на богослужење” (Савић 2013: 969), иако ова лексема постоји и у славеносрпској епохи као филолошки термин преузет из руског језика, са значењем 'акценат' (Ранђеловић 2018: 138), Тешић - не узимајући, према усменом саопштењу песника, у обзир егзистенцију ових термина - гради заправо посве нову реч са потпуно новим значењем, које подразумева и еротичку интонацију целе песме. Стилски поступак уклапања архаичне лексике и индивидуалних неологизма био би неупоредиво тежи да нова реч заправо не опонаша застарелу. О томе пише и сам Тешић (2004: 195):

Ризичан је захват стављање у исти контекст архаичних речи и оних које су, на пример, индивидуални неологизми. Неопходно је да такав стваралачки поступак буде, пре свега, наметнут природом песме: њеним садржајем, темом и мотивима, њеном формом, па и снагом надахнућа, као и другим чиниоцима релевантним за биће одређене песме. Тек таквим литерарним напором може се довести у склад лексика разнородне језичке и стилске обележености. Не значи, међутим, да се испуњењем свих ових лексичких услова унапред обезбеђује висок уметнички досег неке песме.

И у првој збирци Кључ од куће, Милосав Тешић (1992: 126-128) већ је стварао архаизмоиде, али међу њима препознајемо и њихову другачију, народску природу. У песми „Читајући Данила, Свети Марко I-III”- лишеној удаљеније историјске перспективе, песник се сећа свога детињства и раз- 
говора укућана о политици. У томе контексту ваља анализирати и Тешићеве архаизмоиде крпија и грдија, изведене у духу застарелих речи из народа, било да имају глаголску (бугарија, морија) или продевску творбену основу (проклетија, поганија). ${ }^{12}$ Неологизам крпија, са глаголском творбеном основом крn-, практично је и песнички дефинисан у стиховима:

у пјесмином распјеву: Крпљен живот крпија,

а кроз прсле прозоре прелама се Србија!

Иако лако долазимо до значења неологизма грдија у наставку песме, будући да има семантички прозирну придевску творбену основу грд-, песник га додатно нијансира низањем лексема сродног значења:

$$
\begin{aligned}
& \text { А кроз прсле прозоре прелама се Србија, } \\
& \text { бехарају маџарке! Коме ли се природа } \\
& \text { у сретање спремила? - кад је живот грдија, } \\
& \text { таљигање, педепса, а свијетом изрода } \\
& \text { као пасјег накота! - Бруј пчелињи: такуше }
\end{aligned}
$$

5.2. На сличним поетичким поставкама као Милосав Тешић, ствара и песник Томислав Јовановић, којег је јавност до сада пре свега препознавала као врсног тумачања и професора средњовековне књижевности. Од појаве прве песничке збирке Зри зде (2017), у његовој поезији већ је уочен снажан утицај црквенословенског, прецизније српскословенског, језика на саврмени песнички израз. Јовановићева поезија несумњиво је најдубљи и највећи извор архаизмоида у савременој српској поезији. У збирици Зри зде лако је детектовати архаизмоиде налик на архаизме и из црквенословенског и из српског народног језика средњег века. Само као једну илустрацију за прве, условно речено ирквенословенизмоиде, наводимо именичке лексеме добијене комбинованом (сложено-суфиксалном) творбом, у којима запажамо фонетско-деривационо посрбљавање, па место црквенсловенског суфикса -ије препознајемо народни суфикс -је: ирнословље (Урезно гавран-перо / гаче црнословљем 16), новоречје (Пером запојницом / мости новоречја 17), дуготрпље (вида дуготрпље 17), милокрвље (дуби милокрвље 17), словокрасје („Небеска словокрасја”, граматик Гаврило / снује словокрасја 18), крепкоречје (да му се ветрило пера / разослови крепкоречјем 21), светлоречје (да испише тетраднице / медоточног светлоречја 21), грдорађе (Смотри око хитролетно / нетрезвено грдорађе 22), крајелисје (На крајелисју нотад оста / само њему знани белег 24), скудоречје (пером смутног скудоречја 25), криворечје (грешни дијак струже криворечје 26), словосађе (сачинише бело бело словосађе 27), радоживље (радоживљем да прокрве преплет 27), часомерје (На зиду безвременог безвременог часомерја 39), пустинољубље (и настани се у пустинољубљу 49), оштротрпље (босоножи свети Сава / атонско оштротрпље 50), ватростишје („Теодосијева ватростишја” 52, кује ватростишја литургијска 52), даноноћје (Незаситно црнило / тече даноноћјем 53, старо-

\footnotetext{
${ }^{12}$ Упор. Клајн 2003: 82.
} 
живље (речи староизводне / сковане у староживљу 64), старогласје (Наричу трубе старогласја 69) и сл. И неологизми добијени од предлошко-падежних конструкција (до небеса, под небесима, о мраку) извођењем са суфиксом -је такође звуче „старински” и складно се уклапају у контекст: донебесје (закликтале донебесјем / онокрилних светилница 29), поднебесје (туче молитва у поднебесје 68) омрачје (омрачје старости изобрело објављену светлост 40) и сл. ${ }^{13}$

Посебно занимљив пример представља Јовановићева изведеница хиландарје, која је и насловна реч читавог одељка (Јовановић 2017: 35). У песми „Птице хиландарја” (44) овај архаизмоид, дат у последњем стиху (на врлине слећу птице хиландарја) корелила са другим, изведеницом светогорје из првог стиха (Златоречјем изниклим у светогорју). ${ }^{14}$ Архаизмоид Хиландарје, међутим, већ је у својој поезији активирао Бранко В. Радичевић (Милановић 2016), што нас враћа феномену интертекстуалности као битном поетичком поступку при анализи архаизмоида у српској књижевности.

Аутопоетички запис Томислава Јовановића (2017: 202-203) непосредно нас води изворима мотивације за стилистички и поетички поступак грађења архаизмоида. Због значаја овог исказа за тумачење типичне функције архаизмоида у језику савремене српске књижевности, нарочито поезије, наводимо дужи цитат:

Упознајући непрестано тајне српскословенског језика током протеклих деценија кроз наставу српске средњовековнекњижевности и проучавањем рукописног наслеђа, постало ми је блиско да у свој израз уплићем и речи које носе драгоцена значења, не превише далека и савременом човеку [сва истицања курзивом у цитату су наша - А. М.]. Одмеравао са, и ослушкивао звук таквих речи у новом руху српског језика. Уверавао сам се све више да оне сасвим пристају у спојевима на које ни сам нисам до таданавикао, или их сретао веома ретко код појединих српских песника новијих времена. Изнете испод патине векова и оживљене после неправедне затурености, те речи засијале су новим сјајем. Понетмагијом у којој се сусрећу старо и ново, одважио сам се да се отиснем на непознату песничку пучину имајући пред собом блиставе путоказе допрле из ризнице књижевног језика далеких предака. Неке од одлика тог језика, а нарочито склоност ка сажимањима оличеним у сложенииама, много су ми значиле те сам почео да стварам нове кованице. Истовремено, оне су ми биле прави изазов када би искрсавале спонтано или настајале у настојању да дођем до што задовољавајућег решења.

5.3. Већ смо на примеру Јовановићеве поезије („Хиландарје”) видели да архаизмоиди могу у савременој српској поезији заузети и најпробитачнија места текста - наслове одељака, али и читавих дела, као у случају књи-

${ }^{13}$ Упор. и примере Јовановићевих нових изведеница са суфиксом -је, које су само за нијансу мање „видљиве” као архаизмоиди будући да је извођење најтипичнији тип творбе у српском народном језику: књижје (Под липом Гаврило / онослови књижје 17), збежје (На хартији збежја / круни сазданија 17), незајажје (кроти незајажја, / пречи звездочије 17), ресавље (лизне црнило, кропи ресавље 27), треперасје (Цикће узнос попевнице / раздраганог треперасја 29), обилазје (Кружоредним обилазјем / надмећу се словорози 29), пројутарје (несебични појци пројутарја 39), крезубље (По крезубљу тумара сневање о охтоподима 41), слађе (а путиром медног слађа / напојити ноћ псалтирну 46) итд. Сасвим „књишки” звуче пак архаизмоиди обескњижје (Заточен у обескњижју 15), пригревље (добављено из пригревља 46) и др.

${ }^{14}$ Архаизмоид светогорје појављује се касније и у песми „Светогорска ливада” (пресели се из светогорја / у краљеву хрисовољу 49). 
ге Светислава Басаре (2008) о времену Милоша Обреновића, под насловом Majmunoopisanije. Чини нам се да и овај пример показује да је за српске писце и публицисте најуочљивији тип архаизмоида лексема добијена слагањем (композицијом) или комбинованом (сложено-суфиксалном) творбом, са архаичним суфиксом. Међу суфиксима, ту улогу, код оба типа творбе, углавном добија црквенословенски суфикс -ије као стилски најмаркиранији, будући да је из савременога српског језика сасвим потиснут. Исто важи и за изведенице са овим књишким суфиксом, што потврђују примери из поезије Бранка В. Радичевића дати у облицима множине, које би некада припадале вишем стилском регистру, а сада смештене у иронијски контекст: престајаније (Ни бежати, ни пристати, нема престајанија 15), постојаније (Парезанија на макац, на постојанија 16), постраданије (Ни знак, ни труб. Грко ко постраданија 16).

6. Стилогеност архаизмоида у публицистичком стилу. У публицистичком стилу архаизмоиди су заправо карактеристични само за језик савремених колумни. Колумнисти, такође, неретко посежу и за архаизмима у циљу онеобичавања свога стила, а и архаизми и архаизмоиди средства су за исказивање ироније, сарказма и хумора. По овој особини језик савремене српске колумне ближи се језику књижевног есеја, и обрнуто.

Вероватно најбољи пример употребе архаизмоида са наведеним стилским функцијама налазимо у колумнама књижевника Светислава Басаре, писаним за дневне новине Danas. Као средство ироније и сарказма архаизмоиди су у Басариним колумнама активирани неупоредиво ређе од архаизама различитог порекла, од турцизама до славенизама. Готово по правилу архаизмоиди су у тексту измешани са архаизмима. У једној колумни (Басара 2017a) архаизмоид благоизјавити („Da sam ja potpisao Briselski sporazum”tako je JexS Tadić pre neki dan blagoizjavio za Danas - „Srbija bi zacelo gorela”), налик на црквенословенске сложене глаголе, Басара укршта са по пореклу хетерогеним архаизмима трогателно (kako se trogatelno izrazio), чтец и безбели (No, dobro, trezvenoumni čteci će sad bezbeli reći: šta se tu može). У другој колумни (Басара 2017б), такође, архаизмоид попечитељствен (Samo što је smestio sredstvo za rad - to jest dupe - u popečiteljstvenu fotelju, Vulin Aleksandar se vratio korenima), са архаичном основом и савременим суфиксом, у истом је тексту са архаизмима законоправило, дилбер и вактиле. Трећа колумна (Басара 2017в) архаизмоид коментаторлук (Evo, recimo, šta je o moralnoj gonadi u potfamoznom komnentatorluku napisao gonadin bivši zaposlenik), налик на турцизме због суфикса оријенталног порекла, ${ }^{15}$ сада доводи у корелацију са славенизмом подобије (jer je serdar Radoš razbucao sve što je mogao i povukao se u mirovinu, na podobije svog prvog mentora). Тежња ка изразитој лексичкој хетерогености текстова колумни, у којима Басара меша архаизме, неологизме, вулгаризме, колоквијализме, жаргонизме и другу стилски маркирану лексику чак и у једној реченици, очито условљава свесно ауторово мешање,

\footnotetext{
${ }^{15}$ Творбени модел изведеница са суфиксом -лук још увек је творбено активан, али се њиме данас по правилу граде стилски маркиране именице.
} 
укрштање, архаизама и архаизмоида различитог порекла, чиме се ствара утисак свевремености друштвених девијација које се осуђују.

7. Методолошки и практични проблеми при детектовању архаизмоида. Велики почетни теоријско-методолошки изазов представља и пуко детектовање архаизмоида у савременом српском језику. Још већи изазов представљало би, наравно, њихово регистровање у историји српског књижевног језика, нарочито у историји језика српске књижевности. Пре израде добрих историјских речника српског језика, такве истраживачке задатке готово је немогуће решити без велике задршке. Наиме, архаизмоиди се без дијахронијских речника могу само наслутити, на основу доброг језичког осећања или интерних истраживачких корпуса, али се не могу и доказати.

Добар пример представља творбена анализа лексеме зам(j)ешатељство коју је понудио Иван Клајн у монографији о творби речи у српском језику. Пишући о творбеном моделу именица са суфиксом -ство код којих „као основа увек постоји nomen agentis na -mељ”, Клајн (2003: 185, у фусноти 96) констатује: „Изузетак је шаљиви псеудоархаизам зам(j)ешатељство, према коме не постоји (али би се могла замислити) именица зам(j)ешатељ.” Барем два методолошка проблема овде привлаче пажњу историчара језика. Први је да је лексема зам(j)ешатељство квалификована као „шаљиви псеудоархаизам”. Према интерном корпусу аутора овога рада, ова лексема је, међутим, потврђена у Српском народном листу још 1841. године, и то без икаквих шаљивих конотација (замышательство СНЛ 13, 1841, 103 ). ${ }^{16}$ Не чуди ни што је у РСАНУ ова лексема квалификована као разговорна, а илустрована знатно млађим примерима: у корпус за овај речник с разлогом нису узета славеносрпска дела.

Други методолошки проблем лежи у Клајновој тврдњи да „не постоји (али би се могла замислити) именица зам(j)ешатељ.” Да ли је ове именице било у српском језику или није, потврдиће тек будући дијахронијски речници, а то се на основу РСАНУ и РЈАЗУ не може утврдити с обзиром на природу њихових корпуса.

8. Закључак. Наведени примери за архаизмоиде у српском језику и његовим различитим стиловима показују да је овај лексички слој веома специфичан тип (индивидуалних) неологизама: лексеме су нове, али су створене са жељом да личе на оне застареле. То указује на њихову невероватну стилску потентност. Архаизмоиди су, наиме, истовремено двоструко стилски маркирани - као неологизми гледајући целину, тј. читаву лексему, и као архаизми гледајући њихове делове, тј. творбене морфеме. У односу на све друге неологизме, они имају једно стилско обележје више, а то је њихова обличка архаизованост. Будући да су двоструко стилски обележени, и као неологизми и као архаизми, архаизмоиди у српском заслужују много више пажње дериватолога и стилистичара, али и историчара књижевног и стандардног језика.

\footnotetext{
${ }^{16}$ Ваља очекивати да има и старијих потврда.
} 
У савременоме српском стандардном језику архаизмоиди углавном настају у књижевноуметничком и публицистичком стилу. Судећи само на основу ауторовог корпуса, неупоредиво више архаизмоида настаје по угледу на лексичке славенизме (примери типа благоизјавити, мајмуноописаније или дуготрпље) него на застареле речи из српског народног језика (примери типа коментаторлук, крпија или грдија). Разлоге томе треба тражити у већој стилској обележености лексике налик на црквенословенизме и славеносрбизме (како на фонетској тако и на творбеној равни), као и у њиховом снажном ироничном, сатиричном и хумористичном сенчењу када се активирају у есејистици или публицистици. Када се активирају у књижевности, првенствена функција лежи им у евоцирању и приближавању прошлости, као у поезији Милосава Тешића или Томислава Јовановића.

Некадашња диглосија огледа се и у стилистичким функцијама лексичких архаизмоида. При иронији, ако су архаизмоиди редакцијски маркирани, чешћи су облици налик на оне из рускословенског него из српскословенског језика (примери типа атеиствујушчи или марксиствујушчи), на шта је првенствено утицао Вуков веома негативан став према славеносрпској књижевности, у којој су се руски и рускословенски облици несистемски мешали са српским. Када су архаизмоиди грађени по угледу на застарелу народну лексику, што је неупоредиво ређе, они по правилу немају иронично сенчење захваљујући статусу народне и фолклорне традиције од Вуковог времена до данас. Будући да је мало творбених модела и творбених морфема из српског народног језика застарело од времена стандардизације, овакви архаизмоиди су ређи јер аутори схватају како је читаоцима теже да их детектују те не врше очекивану стилску функцију будући да нису ни стилематични.

Ваљало би на самоме крају рада истаћи да би се у србистици из исте стилистичке перспективе могло говорити и о синтаксичким архаизмоидима, при чему бисмо пре свега истакли опонашање барокне реченице из текстова читавог 18. и прве половине 19. века у савременој српској прози, пре свих у романима Радована Белог Марковића.Та тема, међутим, заслужује посебан рад.

Тачност будућих анализа архаизмоида у српском језику биће директно условљена стањем наших ресурса, првенствено судбином започетих дијахронијских речника српског језика у Матици српској (Речника славеносрпског језика и Историјског речника српског језика).

\section{ИЗВОРИ}

Бacapa 2008: Svetislav Basara, Majmunoopisanije, Čačak: Gradac.

Басара 2017a: Svetislav Basara, ,Sto godina sramote”, Danas, 3. avgust, 24.

Басара 2017б: Svetislav Basara, „Nemoralna veličina”, Danas, 16-17. septembar, 24. Басара 2017в: Svetislav Basara, „Dubina interesa”, Danas, 20. septembar, 24.

Давичо 1969: Оскар Давичо, Поезија, отпори и неотпори, Београд: Просвета. Давичо 1974: Oskar Davičo, Rituali umiranja jezika, Beograd: Nolit. 
Делић 1997: Јован Делић, „Божанствена Четири канона”, поговор у: Иван В. Лалић, Четири канона, Београд - Врбас: Српска књижевна задруга - Витал, Београд - Врбас, 9

Јовановић 2017: Томислав Јовановић, Зри зде, Београд: Чигоја штампа.

Кордић 2011: Славко Кордић, „Андрићев човек има руке”, Политика, додатак Култура - Уметност - Наука, 12. новембар, 07.

Мишић 1996: Зоран Мишић, Критика песничког искуства, Београд: Српска књижевна задруга.

Радичевић 1997: Бранко В. Радичевић, Нове песме, Београд: Просвета.

Тешић 1992: Милосав Тешић, Кључ од куће, II издање, Нови Сад - Београд: Матица српска - НИП „Борба”.

Тешић 1996: Милосав Тешић, Прелест севера, круг рачански, Дунавом, Београд: Просвета.

\section{ЛИТЕРАТУРА}

Винавер 2012: Станислав Винавер, Заноси и пркоси Лазе Костића, Београд: Службени гласник.

Грицкат 1994: 29: Ирена Грицкат, „Из историје стабилизације књижевног језика код Срба : после Вукове и Даничићеве победе”, Јужнословенски филолог, L, 5-31.

Грковић-Мејџор 2011: Јасмина Грковић-Мејџор, „Отисци језичке прошлости у делима Лазе Костића”, у: Лаза Костић 1841-1910-2010 (уредник Љубомир Симовић), Београд: САНУ, 59-67.

Драгићевић 2018: Рајна Драгићевић, Српска лексика у прошлости и данас, Нови Сад: Матица српска.

Јовановић 2017: Томислав Јовановић, „Успутна реч”, у: Зри зде, Београд: Чигоја штампа, 201-210.

Клајн 2003: Иван Клајн, Творба речи у савременом српском језику. Други део. Суфиксаиија и конверзија, Београд - Нови Сад: Завод за уџбенике и наставна средства - Матица српска - Институт за српски језик САНУ.

Клајн/Шипка 2008: Иван Клајн и Милан Шипка, Велики речник страних речи и израза, треће допуњено и исправљено издање, Нови Сад: Прометеј.

Мацановић 2018: Ана Мацановић, Српска језикословна терминологија у 19. веку, Београд: Институт за српски језик САНУ.

Милановић 2002: Александар Милановић, „Стевановићева виђења предвуковског периода развоја српског књижевног језика", у: Живот и дјело академика Михаила Стевановића, Подгорица, 315-329.

Милановић 2003: Александар Милановић, „Архаизовани језик савремене српске прозе”, у: Савремена српска проза, 15, Трстеник: Народна библиотека „Јефимија”, 123-142. 
Милановић 2013: Александар Милановић, „Однос Оскара Давича према црквенословенском језичком наслеђу”, у: Песничка поетика Оскара Давича, Београд - Шабац, 141-156.

Милановић 2016: Александар Милановић, „Индивидуални неологизми у Новим песмама Бранка В. Радичевића", у: Поезија Бранка В. Радичевића (прир. Драган Хамовић), Чачак - Београд: Градска библиотека „Владислав Петковић Дис" - Институт за књижевност и уметност, 103-115.

Мишић 1996: Зоран Мишић, Критика песничког искуства, Београд: Српска књижевна задруга.

Мухвић Димановски 2005: Vesna Muhvić-Dimanovski, Neologizmi: problemi teorije i primjene, Zagreb: Zavod za lingvistiku Filozofskoga fakulteta Sveučilišta u Zagrebu.

PJA3У: Rječnik hrvatskoga ili srpskoga jezika, I-XXIII, Zagreb: Jugoslavenska akademija znanosti i umjetnosti, 1880-1976.

PMC: Речник српскохрватскога књижевног језика, 1-6, Нови Сад (- Загреб): Матица српска (- Матица хрватска), 1967-1976.

РСАНУ: Речник српскохрватског књижевног и народног језика, 1-19, Београд: Институт за српски (српскохрватски) језик САНУ, 1959-2014.

Савић 2013: Виктор Савић, Богослужбена лексика у српским типицима од $X I I$ до XIV века, трећи део, Нови Сад: Филозофски факултет [необјављена докторска дисертација].

Стијовић 1992: Светозар Стијовић, Славенизми у Његошевим песничким делима, Сремски Карловци - Нови Сад: Издавачка књижарница Зорана Стојановића.

CXJ 1971: Srpskohrvatski jezik, Enciklopedijski leksikon - Mozaik znanja, Tom 1 , Interpress, Beograd.

Тешић 2004: Милосав Тешић, Есеји и сличне радње, Београд: Завод за уџбенике и наставна средства.

hopau 1968: Milorad Ćorac, Jezik i stil Mihaila Lalića, Priština: Zajednica naučnih ustanova Kosova i Metohije.

hopaщ 1974: Milorad Ćorac, Stilistika srpskohrvatskog književnog jezika, Beograd: Naučna knjiga.

hорић 2008: Божо Ћорић, Творба именица у српском језику (одабране теме), Београд: Друштво за српски језик и књижевност Србије. 
Aleksandar M. Milanović

\section{LEXICAL ARCHASMOIDS I.E. PSEUDOARCHAISMS IN CONTEMPORARY SERBIAN} LANGUAGE

\section{Summary}

The paper brings the results of author's analysis of archaismoids, in which are implied the neologisms, most frequently individualisms produced consciously after the archaic word-formational type or by use of archaic word-formational morphemes. Author defines their origin and their stylistic function (styles markedness) in publicist and belletrists styles in Serbian standard language. 